\title{
Die Bybel in die geding: Teks versus dogma
}

\author{
Lina Spies \\ Departement Afrikaans en Nederlands \\ Universiteit van Stellenbosch
}

\begin{abstract}
The Bible at stake: Text versus dogma

This article concentrates on one of the great achievements of postmodernism regarding theology: the highlighting of the inseparable relation between religion and poetry. The article argues that, as we are unable to fashion a dependable representation of our world and of God, we have to return to the text and to the language of belief as sole way of expressing our thoughts about God and about belief. The language of belief is not the language of dogma, but that of poetry, and the language of poetry is figurative language. In illustration of this, the text of Samson is reread not as factuallytrue history, but as the tragic story of a person whose God-given calling and talents are in conflict with his natural drives and gifts, but whose heroic death nevertheless ultimately serves to glorify God. In conclusion the article pleads for the liberation of the Bible from the Greek-Roman construction of it, so that it may again begin to tell stories through which the reader may learn to comprehend something of God. So, too, the Jewishness of Jesus, which has been eroded by dogma and preaching, may be rediscovered.
\end{abstract}

\section{DIE "NUWE SUID-AFRIKA" EN DIE KRISIS VAN SEKERHEDE}

Suid-Afrika het van 'n geïsoleerde land aan die verre suidpunt van 'n vreemde en grootliks onbekende kontinent 'n land geword in die "global village" van die een-en-twintigste eeu. Meer nog: op die vooraand van die eeuwisseling en die aanbreek van die nuwe millenium het Suid-Afrika 'n ingrypende politieke transformasieproses binnegegaan. In 1994 het daar 'n einde gekom aan 'n politieke beleid, gebaseer op rasseskeiding, wat wêreldwyd veroordeel is en die hoofoorsaak was van die isolasie van die land in die tweede helfte van die twintigste eeu.

Die val van die Berlynse muur het die skeidsmure tussen Suid-Afrika en die buiteland en Suid-Afrikaners onderling laat verkrummel. In beginsel het elke Suid-Afrikaner die wegval van hierdie grense aan die lyf gevoel. Die isolement van eeue en 'n veertigjaarlange beleid van apartheid wat nog tot só onlangs as die negentigerjare gehandhaaf is, kon deur 'n demokratiese 


\section{Die Bybel in die geding: Teks versus dogma}

verkiesing opgehef maar nie onmiddellik ongedaan gemaak word nie. Die opheffing van isolasie is ' $n$ voortgaande proses en die bevryding wat dit bring, impliseer blootstelling wat uiteraard dikwels 'n ontstellende en pynlike ervaring is. Die grense wat geskei het, het by al die vervreemding wat dit veroorsaak het, ook beskerming verleen; beskerming van dít waaraan mense hulle ten diepste verbonde voel - die eie taal, kultuur en godsdiens.

Deur sy isolasie was die kerk in Suid-Afrika afgesny van die debat wat sedert die Tweede Wêreldoorlog in die res van die Christelike wêreld, in die besonder binne die Europese Christendom, gevoer is. Ons het wel gehoor van die "vrot wrakstukke wat uit Europa op ons skoon kuste uitgespoel het". Diegene wat anders gedink het, het - op uitsondering van enkele moedige individue na - geswyg teenoor die meerderheid wat in hulle arrogansie daarvan oortuig was dat hulle in teenstelling met die "afvallige en dekadente Europeërs" die waarheid aan hulle kant gehad het. Dis egter nie langer moontlik om die deksel op die kokende pot te hou nie.

Boeke kon tydens die apartheidsperiode verban word, maar in die hede kom via die media - veral via die internet - inligting tot binne in die intieme ruimte van jou studeerkamer. Afrikaners het begin dink en dit kan hulle nie meer verbied word nie. Verkettering en daaruit voortvloeiende ostrasering, hoe pynlik en onaangenaam dit ook al is, is die ergste wat andersdenkendes vandag bedreig. Dit is nie meer moontlik om mense in die huidige tydvak die swye op te lê waar dit vir hulle gaan om hulle diepste oortuigings nie.

Die gesprek wat tans in en buite die kerk gevoer word, sentreer om die gesag van die Bybel en die goddelikheid van Jesus. Die debat is nie van nou of van gister nie; dit is reeds vir eeue aan die orde. Ortodokse gelowiges waaronder ek diegene verstaan wat hulle oor alle vrae in verband met die Christelike geloof beroep op die gesag van die Bybel as die onfeilbare Woord van God - beweer dat die huidige debat om vraagstukke handel waarop in die loop van die geskiedenis afdoende antwoord gegee is.

Maar die geskiedenis is altyd in beweging en die mens stagneer nie binne 'n sekere tydvak nie. Om te beweer dat die hedendaagse mens dieselfde is as die mens van die vierde of vyfde eeu na Christus toe die Christelike dogmas beslag gekry het, druis in teen alle redelikheid. Daar is vrae wat die mens van alle tye vra, maar altyd binne 'n ander konteks. Die Renaissance-mens het anders gedink as die Middeleeuer. Binne postmodernistiese konteks dink ons anders as wat ons as erfgename van die modernisme gedink het.

Geen mens kan hom afsluit van 'n kulturele stroming nie; jy is deel daarvan of jy wil of nie. Die besef dat ons "kinders van ons tyd" is, het egter nog nie in genoegsame mate by ons gedaag nie. Die godsdiensdebat aan die 
tuisfront is dus ten diepste 'n bewusmakingsveldtog. Terselfdertyd is dit 'n inhaalaksie, want nie alleen is ons in die twintigste eeue uitgesluit van die groter teologiese debat in die wêreld nie; ná die saak wat die kerk in die dertigerjare teen prof Johannes du Plessis van die Teologiese Seminarium op Stellenbosch gevoer het, is die ontwikkeling van die teologiese wetenskap min of meer lam gelê. Hy is verketter omrede van sy siening dat Jesus by sy menswording sekere van sy goddelike eienskappe afgelê het, dat Moses nie die skrywer van die Pentateug in sy geheel kon gewees het nie, omdat 'n mens nie sy eie begrafnis kan beskryf nie, en dat die verhaal van Jona in die buik van die vis 'n mite is en nie 'n historiese gebeurtenis nie. Sonder kritiese denke is daar van wetenskapsbeoefening in die ware sin van die woord geen sprake nie.

\section{DOGMA EN SKRIFGESAG}

WAT (die Woordeboek van die Afrikaanse Taal) definieer dogma onder andere as die "geheel van gelowige besinning oor die Skrifopenbaring wat deur die kerk geformuleer en met gesag as geloofswaarhede voorgedra word." As 'n mens die kernbegrippe uit hierdie nogal lomp en omslagtige definisie lig - "Skrifopenbaring", "gesag", "geloofswaarheid" - kom dit daarop neer dat die kerklike dogma geformuleerde geloofswaarhede is wat met die Bybel as die geopenbaarde Woord van God ooreenstem en daarom absolute gesag het.

Vanaf die begin van die Christelike jaartelling is 'n lang en moeisame weg afgelê na die formulering van "geloofswaarhede". Karen Armstrong wys in haar omvattende en indringende studie oor die drie monoteïstiese godsdienste (die Judaïsme, die Christelike godsdiens en die Islam), A history of God, op die onstuimige en folterende gebeure en die pynlike stryd wat die definiëring van die Christelike dogmas voorafgegaan het: "The turbulent events of the fourth and fifth centuries would lead to a definition of orthodox belief only after an agonising struggle" (Armstrong 1996:119).

Oor die goddelikheid van Christus was daar in die vroeë kerk groot verdeeldheid, ook onder die biskoppe wat op 20 Mei 325 in Nicaea byeengekom het. Hulle het hulle op die slingerbaan bevind êrens tussen twee standpunte wat onderskeidelik verteenwoordig is deur Arius en Athanasius. Arius het die essensiële onderskeid tussen God en al sy skepsels beklemtoon. Jesus was, soos Johannes in die proloog van sy evangelie sê, die Logos en dié Logos was God. Nogtans was hy nie van nature God nie; dié status is deur God vooraf aan hom verleen omdat God geweet het dat die Woord wat vlees geword het, Hom sou gehoorsaam. "But Jesus's divinity was not natural to him; it was only a reward or gift" (Armstrong 1996:128). 
Vir Athanasius in teenstelling tot Arius kan die Logos nie met ' $n$ kwesbare wese vereenselwig word nie. Deur die Logos het God geskep en hou Hy die geskape werklikheid in stand sodat dit nie disintegreer en oplos tot niks nie. Die Logos het neergedaal in ons verganklike wêreld van dood en korrupsie sodat ons deel kan hê aan God se onsterflikheid. "Only he who created the world could save it, and that meant that Christ, the Logos made flesh, must be of the same nature as the Father" (Armstrong 1996:130).

Die pendule het na die kant van Athanasius geswaai en met slegs Arius en twee van sy geesgenote wat geweier het om te teken, het die dogma van die Goddelikheid van Christus (die Skepper en die Verlosser is één) in die Geloofsbelydenis van Nicaea uitdrukking gevind ${ }^{1}$ :

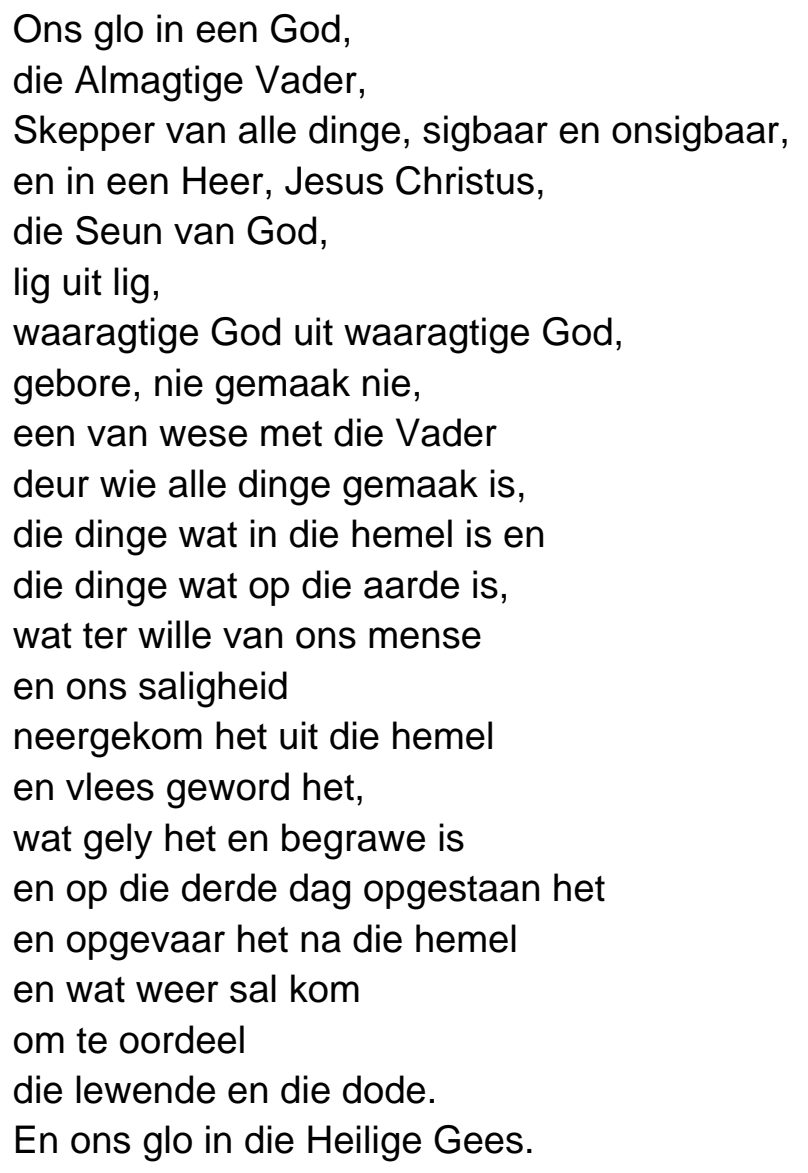

Die eenwees van die Vader en die Seun word in Afrikaans weergegee met "wese" vir die Griekse woord "homoousion" wat Karen Armstrong (1996:131) vertaal met "of the same stuff"; dit wil sê van dieselfde "substansie". Sy wys daarop dat dié term uiters kontroversieel was weens die onskriftuurlikheid daarvan en die materiële konnotasies daaraan verbonde. Die kompromis wat biskop Marcellus voorgestel het was om die Seun nie te beskryf as "van

\footnotetext{
${ }^{1}$ Ek gee Karen Armstrong $(1996: 130,131)$ se Engelse vertaling, met behoud van haar tipografie, van die Geloofsbelydenis van Nicaea so getrou moontlik in Afrikaans weer.
} 
dieselfde soort" (homoousion) as die Vader nie, maar as "van soortgelyke aard" (homoiousion) as die Vader. Waarop dit neergekom het, was dat diegene wat hulle by Athanasius geskaar het, wat dit nie volkome met mekaar eens was oor hoe hulle die eenwees van God in Christus moes verstaan nie, hulle geledere gesluit het teen Arius: "Those who said that the Logos was of the same nature as the Father and those who believed that he was similar in nature to the Father were "brethen'" (Armstrong 1996:132). Hulle meningsverskil was ten diepste 'n kwessie van terminologie, is geredeneer.

\section{DIE BYBEL AS LITERATUUR}

As daar tussen die biskoppe by Nicaea soveel meningsverskil was oor die Goddelikheid van Christus, is dit nie verbasend nie maar vanselfsprekend dat die debat binne die konteks van ons tyd weer opgevlam het. Die geloofsleer wat in die besinnende periode na die daeraad van die Christendom sy beslag gekry het, het implikasies wat vir die gelowige in die hipertegnologiese samelewing van die hede, nie net onaanvaarbaar is nie, maar selfs aanstootlik.

Van Augustinus - saam met Paulus die grondlegger van die Latynse Christendom - het ons die leer van die erfsonde. Hierdie leer wat steeds 'n groot rol speel in die Westerse Christendom is ' $n$ aanstoot vir die bevryde en gesofistikeerde hedendaagse mens, in die besonder vir die geëmansipeerde vrou. Die eerste stelling in die doopsformulier gaan direk terug op Augustinus wanneer ouers wat hulle kinders deur die doop in die verbond wil laat opneem, moet bely: "dat ons met ons kinders in sonde ontvang en gebore word en daarom kinders van die toorn is ...". Met hierdie woorde bely ons wat Augustinus geglo het, naamlik dat die ganse mensdom verdoem is deur die sonde van Adam wie se skuld deur middel van die seksuele daad - besoedel deur wellus - van geslag tot geslag oorgedra word. Augustinus se dogma van die erfsonde het ons as sy erfgename slagoffers gemaak van 'n selfvervreemding deur selfhaat. Dié vervreemding is nêrens opsigteliker nie as in die denigrering van seksualiteit in die algemeen en die vrou in die besonder (Armstrong 1996:145).

Ek is ' $n$ vrou en 'n digter, daarom kan ek my volkome vereenselwig met Karen Armstrong se afwys van die leer van die erfsonde en met haar uitwys van die ironie daaraan verbonde. Terwyl daar hardnekkig vasgehou word aan die vleeswording van God in Jesus waardeur Hy in ons menslikheid kom deel het, is dit bitter ironies dat dit nie tot waardering van die liggaam gelei het nie, maar juis tot die teendeel daarvan: veragting (Armstrong 1996:146). Ek kan vanuit my opvoeding en menswees nóg my liggaam nóg my vrouwees verag.

My ouers het nooit iets anders aan my oorgedra as dat hulle bly was oor my nie: bly omdat ek hulle kind was, bly omdat ek 'n meisie was. Dit is 'n 
geesteshouding, sê Erich Fromm (1956:41), "which instills in the child a love for living, which gives him the feeling: it is good to be alive, it is good to be a little boy or girl, it is good to be on this earth!" As mens verheug ek my aan my vrouwees en aan my verbondenheid aan die aarde en my liggaam, ook miskien veral - omdat ek weet hoe sterk my digterskap daarmee gemoeid en daarvan afhanklik is: "The body is poetry's door, the sounds of words throbbing in legs and arms - let us into the house" (Donald Hall: The unsayable said). Maar my waardering van die liggaamlike, aardse en konkrete hou nie slegs verband met my as mens en digter nie, maar ook met my as wetenskaplike. Aan die grond van my huidige herbesinning oor die Christelike godsdiens lê sowel my literêre geskooldheid as my studie in die filosofie aan die Universiteit van Stellenbosch. Ek dra sedert dié tyd kennis van die Griekse filosofie en van Plato se siening van die stoflike werklikheid as ' $n$ floue afskynsel van die volmaakte Ideëryk waarna die siel, gekerker in die liggaam, by die dood ontsnap. Die filosoof Johan Degenaar het dit reeds by my tuisgebring dat, in teenstelling met Plato se leer, die mens nie sy liggaam bewoon nie, maar dat hy self sy liggaam is in al die uitdrukkings daarvan: religieus, psigologies, eroties, en wat nog verder die inhoud van menswees uitmaak. Eweneens het Degenaar by my die besef laat daag dat die filosofie van Plato wesensvreemd is aan die Hebreeuse denke soos wat dit neerslag vind in die Bybel.

Dié insigte word tans by my bevestig en verskerp deur die hedendaagse filosofie en teologie waarin ek my verdiep. Die filosoof Theo de Boer met sy fyn aanvoeling vir en kennis van die poësie wys die spreke oor die geïnkarneerde gees af omdat dit veronderstel dat daar eers ' $n$ gees is wat vervolgens 'n liggaam kry. Hy konkludeer: "Het levende lichaam is het uitgangspunt" (De Boer 1999:15) en siteer vervolgens die passasie uit Psalm 139 waarin die wondere van die liggaam besing word. Psalm 139 as een van my mees geliefde psalms behoort tot die agt herdigte liedere wat ek bygedra het tot die Liedboek van die Kerk. Die psalmdigter se lof op die mens se ontstaan en bestaan as liggaamlike wese het ek as volg weergegee:
Bekend is $U$ met al my tye van voor my eerste daeraad.
Ook was ek nooit vir $\mathrm{U}$ verborge, maar altyd voor $U$ oop en bloot - $\cup$ het my meesterlik geskape in die geheime moederskoot. $\mathrm{U}$ sluit vanaf my vrugbegin my in $U$ troue liefde in. ${ }^{2}$

\footnotetext{
${ }^{2}$ Ek het in samewerking met prof Andries Breytenbach Ps 139 herdig. Graag erken ek my skatpligtigheid aan hom vir sy uitstekende eksegese.
} 
Ek kan my volkome vereenselwig met wat die digter-teoloog Willem Barnard (2004:43) in sy gepubliseerde dagboek van 1981 sê in verband met sý kerkliedere
ledere kerk die kleiner is dan de hele kerk, is mij te klein, we kunnen alleen ademen in de hele kerk. Maar áls ik ergens versjes van mijzelf tegenkom en ik zing ze mee, ik voeg mijn partikeltje weer in dat ego van de zingende kerk ... dan komen die liederen die ik zelf geschreven heb mij tegemoet, moederlijk, troostend, volwassen.

As Bybels- en literêrgevormde persoon kan ek die Woord - soos die woord nie loslaat nie. Los van die Bybel is ek eweneens nie in staat om my Godsbegrip te vorm nie. Ek glo nie dat enigiemand uit 'n Christelike tradisie, veral die gereformeerde tradisie, dit kan doen nie. Jou denke is nie ' $n$ tabula rasa nie; jy is gevorm deur jou opvoeding. Niemand is daartoe in staat om in die strengste sin van die woord oorspronklik te dink nie; jy is onwillekeurig 'n draer van tekste en word gedra deur tekste. Jy is natuurlik ook 'n draer van ervarings en omdat mense se ervarings verskil, sal hulle Godsbegrip uiteraard ook verskil. Maar sinvolle dialoog word onmoontlik as individue hulle Godsbegrip slegs vorm na aanleiding van eie ervarings en nie meer uit individuele ervarings in samehang met Bybelse - en ander - tekste nie.

Die geloofsbelydenis van Nicaea sluit af met die konstatering "en ons glo in die Heilige Gees" - byna as 'n nagedagte. Soos oor die Vader en die Seun was en is daar oor die "persoon van die Heilige Gees" teenstrydige standpunte. Hy het met sy uitstorting na die kruisdood van Jesus (Hand 2) die bevreesde apostels geïnspireer om die Christelike boodskap na die heidene uit te dra. Aan die Heilige Gees word dus veral gedink as 'n inspirator, in besonder as dié een deur wie die Bybel "ingegee" is. Hy, as inspirator, verleen gesag aan die Bybel as die "geïnspireerde Woord van God".

C J den Heyer (2000:68) sê in die verband:

Hoewel de christelike traditie nooit officieel heeft uitgesproken dat dit goddelijk Woord kant-en-klaar vanuit de hemel op aarde zou zijn neergedaald, scheelde het op de keper beschouwd soms niet veel. Lange tijd was het gebruikelijk de menselijke factor in het ontstaansproces als minimaal te bestempelen. Niemand minder dan de Geest van God werd als de eigenlijke auteur van de gehele bijbel beschouwd. 


\section{Die Bybel in die geding: Teks versus dogma}

Daar is 'n groot verskil tussen die geloof in inspirasie as 'n besielende, kreatiewe krag en die geloof in inspirasie as afkomstig van God by wyse van 'n soort direkte diktaat. Digters wat nie net verstandelik nie, maar ook intuïtief met hulle medium, die woord, omgaan, het dikwels 'n byna Bybelse begrip van inspirasie. ${ }^{3}$ Hulle ken dit as die frase of reël wat van êrens vandaan as 't ware aan die ruit van die bewussyn kom klop of die skielike inval wat jou meedoënloos dwing om sonder versuim daaraan vorm te verleen deur die woord. Bybelsgevormde digters het 'n sterk aanvoeling vir die passasies in die Bybel wat gaan oor die skeppende Gees van God.

Martinus Nijhoff begin die proloog van sy grootse gedig "Awater" met die aanroep: "Wees hier aanwezig, allereerste geest,/die over wateren van aanvang zweeft." Gerrit Achterberg sê in sy gedig "Ontwaken" - een van die tallose verse waarin hy die Orpheus- Eurudike-motief ontgin - dat die woord in die donker "brandend" was "van den Heilige Geest" sodat die moontlikheid bestaan het om die geliefde se dood deel te maak van hulle lewensverhaal. Maar by daglig beskik die woord nie meer oor sy magiese krag nie: "Ik weet het nie, het woord is anders /dan het in 't donker is geweest." Die magtelose digter se "Gebed aan het vuur" is 'n gebed om inspirasie in 'n taal wat in sfeer en beeld suiwer Bybels is:

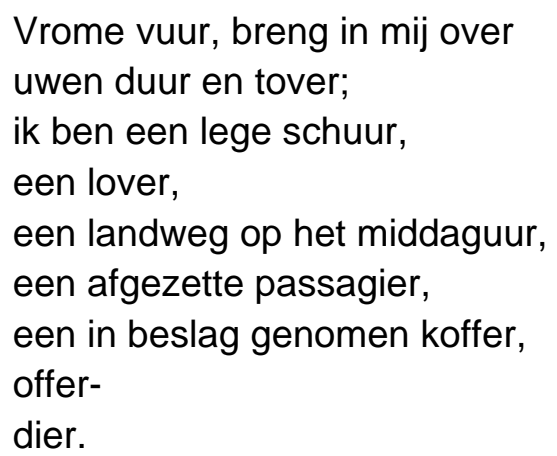

Kristien is in D J Opperman se "Kroniek van Kristien" 'n Noorse meisie wat op die Zoeloelandse sendingstasie werk en van God die vreemde opdrag kry om deur gedaantewisselinge die "pyn van ander" te leer ken. As 'n papajaboom neem sy die gestalte van 'n gekruisigde aan en verkondig in haar preek vir die papajabome op Bybelse wyse die besieling deur die Heilige Gees:

..."Al is ons vas

as mannetjies en wyfies tussen grond en lug ewig in die spel gevange van bevrug, is daar 'n Groen Wind wat só vervoer dat ons ons kan losdans sonder om te roer ..."

\footnotetext{
${ }^{3}$ Digters is natuurlik makers; vakmense wat ernstig nadink oor die beginsels en probleme van hulle vak.
} 
Opperman lê 'n opsigtelike verband tussen die preek van Kristien en Handelinge 2; die "Groen Wind" (met hoofletters geskryf) verwys na die stormwind wat met die uitstorting van die Heilige Gees gepaard gegaan het: "Skielik was daar 'n geluid uit die hemel soos van 'n geweldige stormwind, en dit het die hele vertrek gevul waar hulle gesit het" (Hand 2:2).

Die Bybel bevat boeke wat ' $n$ mens dadelik eien as literatuur soos die poëtiese boeke van die Ou Testament: Psalms, Spreuke, Prediker en Hooglied. Job wat die verhaal vertel van 'n mens wat in 'n kosmiese stryd tussen die goeie en die bose betrek word, het sublieme poëtiese gedeeltes. Rut en Ester is romans in deurlopende prosa geskryf met 'n stygende spanningslyn en 'n ontknoping aan die einde. Die gelykenisse wat Jesus vertel het, is onteenseglik literatuur. As "geformuleerde werklikheid" is literatuur 'n omvattende begrip en kan die Bybel, in sy geheel, as sodanig beskou word. Ek self glo dat die Bybel "geïnspireerd" is maar in dieselfde mate as wat ander literatuur dit is: "De Geest van God maakt gebruik van mensen. Een ander 'kanaal' is er niet. Het 'woord van God' hebben we in dit mensenwoord. Daarmee moeten we tevreden zijn en daarmee moeten we het doen" (Den Heyer 2000:92).

Ek het geleer om die Bybel as literatuur te lees; in eie reg, met respek vir die verskillende genres wat deur die verskillende boeke verteenwoordig word. Dit impliseer dat ek die Bybel ook nie deur die bril van die dogma lees nie. In die Bybel hoor ons inspirerende woorde oor dié God wat ons nooit regstreeks kan leer ken nie, maar slegs deur metaforiese taal wat wesenlik die taal is van die poësie, die liefde en die geloof.

\section{4. 'N MENS KAN OOK ANDERS GLO: 'N POSTMODERNISTIESE PERSPEKTIEF}

'n Studie van die letterkunde lei gou tot die besef van hoe nou die poësie verbonde is met die religie. ' $n$ Mens hoef maar net te dink aan die groot Engelse Metaphysicals, George Herbert en John Donne, en die Protestantse Revius en Rooms-Katolieke Vondel in Nederland wat gedurende die sewentiende eeu hulle onderskeie letterkundes verryk het met hulle religieuse poësie.

Die Nederlandse teoloog Herman Wiersinga het met sy boek Op ooghoogte: Portret van een postmoderne geloof my oë geopen vir hoe die postmodernisme die poësie en religie opnuut bymekaar uitgebring het in wat met reg ' $n$ onlosmaaklike verbintenis genoem kan word. Wiersinga (2000:25) wys daarop dat postmodernisme ' $n$ minder belade term is as "postAuschwitz", maar dat die postmodernisme wel alles te doen het met die 
vernietigingskampe. Die postmodernisme kan, filosofies gesien, teruggevoer word na die breuk met die Duitse Idealisme en op gebied van die literatuur na die verskyning van James Joyce se roman Ulysses. Na die Tweede Wêreldoorlog het dit 'n duidelike kulturele stroming geword.

In sy boek Modernity and the Holocaust laat die sosioloog Zygmunt Bauman geen moontlikheid van twyfel daaroor bestaan dat Hitler die sukses van sy uitroeiingskampanje teen die Europese Jodedom te danke gehad het aan die tegnologiese prestasies van die twintigste eeu nie. Die uitstekend georganiseerde spoorweë van moderne Europa het nuwe roumateriaal mense - na die fabrieke vervoer. In die gaskamers het die slagoffers die gifgas ingeasem, afgegee deur tablette wat deur die gevorderde Duitse industrie geproduseer is. Ingenieurs het die krematoria ontwerp (Bauman 1995:8). ${ }^{4}$

Die keersy van die Verligting met sy vertroue in die mens en die rede het deur die Tweede Wêreldoorlog fel aan die lig gekom. Die wortels van die postmoderne beweging lê in die bankrotskap van die "moderne" Verligtingskultuur: "dankzij haar technisch vermogen en rationele beheersing bleek deze moderniteit in staat massabombardementen en miljoene slachtingen aan te richten" (Wiersinga 2000:25). Wiersinga wys daarop dat die volle effek van die omslag van die Verligtingsideaal in sy teendeel eers enkele dekades na die Tweede Wêreldoorlog deurgedring het.

'n Mens wil byvoeg: tot die Westerse wêreld en Europa in die besonder, maar nie tot Suid-Afrika nie. Ek glo vas dat die onbegrip vir 'n teologie wat hom teen die ortodoksie keer, veral toe te skryf is daaraan dat Afrikaners nog nooit werklik erns gemaak het met Auschwitz nie. Ons sal eers in die gees in Auschwitz moet gaan staan en iets van dié verskrikking aan die lyf moet voel om te begryp wat op die gebied van die hedendaagse teologie gebeur.

Met die wantroue in die rede hang die wantroue saam in taal om die werklikheid weer te gee. Dit is veral 'n artistieke ontdekking en dié ontdekking

\footnotetext{
${ }^{4}$ [Auschwitz] was also a mundane extension of the modern factory system. Rather than producing goods, the raw material was human beings and the end-product was death, so many units per day marked carefully under the manager's production charts. The chimneys, the very symbol of the modern factory system, poured forth acrid smoke produced by burning human flesh. The brilliantly organized railroad grid of modern Europe carried a new kind of raw material to the factories. It did so in the same manner as with other cargo. In the gas chambers the victims inhaled noxious gas generated by prussic acid pellets, which were produced by the advanced chemical industry of Germany. Engineers designed the crematoria; managers designed the system of bureaucracy that worked with a zest and efficiency more backward nations would envy. Even the overall plan itself was a reflection of the modern scientific spirit gone awry. What we witnessed was nothing less than a massive scheme of social engineering ..." (Feingold, How unique is the Holocaust, pp 399-400).
} 
in die kunste is die bakermat van die postmodernisme as tydsverskynsel sedert die sestigerjare van die twintigste eeu (Wiersinga 2000:22). Tekste genereer tekste en wat agter of anderkant die tekste lê, weet ons nie. Ons kan geen betroubare voorstelling van ons wêreld of van God maak nie.

Die wantroue in die voorstellingsvermoë van taal of die kenbaarheid van die werklikheid beteken nie dat taal self onbelangrik word nie. Die teendeel is waar. Waar die outomatiese vertroue in die band tussen woord en waarheid aangetas is, het, soos Wiersinga (2000:123) tereg sê, die waardering vir ander taalvorme as dié van die verslag en die betoog toegeneem. Hy verwys in dié verband na die "tweede taal" wat die priesterdigter Huub Oosterhuis (2000:124) omskryf as die "taal van wat eigenlijk niet te zeggen is. Die je spreekt om niet helemaal te hoeven zwijgen." Dis 'n onmisbare omgangstaal, nie in die sin van die gemaklike daaglikse spreektaal nie, maar in die sin van 'n intieme taal waarin fyn geluister word. Dit is die taal van weinig maar presies gekose woorde; "taal die oproept en uitdaagt, verwijst en open laat" (Wiersinga 2000:124).

Die "tweede taal" is ten diepste die taal van die poësie. Vir 'n digter wat ook intens belangstel in die religie en wat van vroeg-af weet van die dun membraan wat daar is tussen religie en poësie, is wat Wiersinga daaroor sê, bevestigende, bevrydende en hartversterkende uitsprake. As illustrasie van die identiteit van religie en poësie haal hy ' $n$ fragment uit ' $n$ gedig van die Australiese digter Les Murray in Nederlandse vertaling aan:

Religies zijn gedichten. Ze verenigen ons daglicht-ik en onze dromende ziel, ze brengen onze emoties, instinct, adem en aangeboren gebaren bij elkaar in het enige hele denken: poëzie.

Hy vervolg: "Het gedicht zegt dat wie iets van poëzie begrijpt ook gevoel heeft voor religie. Poëzie is het enige 'hele' denken omdat het denken, dromen en ademen omvat ... zonder poëzie mist de religie haar beweeglijkheid en flonkering" (Murray 2000:126, 127). Geloofstaal is die taal van die poësie en die taal van die poësie is wesenlik beeldtaal. As mens die Bybelse woordeskat ontdoen van histories-aangepakte dogmatiese modelle, bestaan dit uit meersinnige en meerdimensionele metafore (Wiersinga 2000:128). Dié onbevange, beeldende taal moes egter plek maak vir die taal van rasionaliteit, eenduidige formulering en presiese omskrywing (Wiersinga 2000:129). Die modernisme het die taal van die Verligting gespreek - hoe letterliker, hoe leër (Wiersinga 2000:131) - maar die postmodernisme maak weer kreatiwiteit en verbeelding los en stel ons in staat om met ander oë te kyk - al is dit op eie ooghoogte en dus met ' $n$ beperkte visie. Daarom maak die postmodernisme ' $n$ 
mens ook beskeie en moet waardes soos goedheid, skoonheid en waarheid opnuut geyk word. Dit beteken dat allesweterigheid moet plek maak vir beskeidenheid; dié beskeidenheid wat eie was aan die latere Van Wyk Louw wanneer hy sê: "Van God durf ek skaars praat: ek ken Hom min" ("Die ambag"). En nog treffender in die slotstrofe van "Ex unguine leonem":

\footnotetext{
Wat ek van mense of van God wil meen, word in my dofheid dof.

lets staan in sterre-en-helderte geskryf;

en ek skryf ná in stof.
}

Die taal van die dogma is nie die "tweede taal" waardeur die onsêbare gesê word nie. Wiersinga herken in die belydenis van Nicaea wel 'n poëtiese moment in die karakterisering van Jesus as "God uit God, Licht uit Licht" maar dié beeldende, fantasieryke hiperbool vir die enorme betekenis van Jesus vir die mensdom word eenduidig en dogmaties verklaar in wat daarop volg: "waarachtig God uit waarachtig God ..." (Wiersinga 2000:143). Wat betoog word oor die wese van God waarin Jesus deel, stel die hedendaagse mens voor probleme wat onbeantwoord bly soos die geval was tydens die biskoppekonferensie van Nicaea in $325 \mathrm{nC}$.

Die taal van die dogma is abstrak, betogend en konfronterend in teenstelling met die taal van die poësie wat beeldend, meevoerend en oortuigend is. Ek het soos Wiersinga (2000:169) begrip vir Willem Barnard se opmerking dat die teks van die credo hom nie steur nie solank dit net nie opgesê nie, maar gesing word. Barnard (2004:16) teken in dié verband in sy dagboek aan: "De kerk spreekt niet. De kerk zingt. Op een voorgeschreven wijs. De kerk viert de liturgie." Die musiek waaraan die poësie nou verwant is, verlos die dogma momenteel uit sy verstarring in onpoëtiese taal. Die diskoers wat die Metaphysicals in hulle religieuse verse gevoer het, was dié van die dogma, maar weergegee in die taal van die poësie. Helen Gardner (1971:193) wys op "the freedom with which they bring ... their native powers of mind, their skill in argument and wit, to play over religious doctrine... This is seen in their confident use of language" (my kursivering).

\section{DIE VERHAAL VAN SIMSON}

Die beskouing van die Bybel as die geïnspireerde Woord van God skep vir die hedendaagse mens wat nog vasgevang sit in die Verligtingsdenke van die modernisme - dikwels sonder dat hy dit besef - ernstige probleme. Dié probleme word enorm vergroot as hy boonop aan God dink in terme van die eienskappe wat die Verligtingsfilosowe aan Hom toegeken het: Hy is die alwetende en alwyse, die algoeie en almagtige Opperwese (Wiersinga 
2000:99). In ooreenstemming met hierdie Godsbegrip moet die Bybel waar wees en moet niks daarin staan wat strydig is met die veronderstelde eienskappe van God nie.

Met hierdie Godsbegrip hang saam die geloof in die vermoë van taal om die werklikheid weer te gee. Op rasionele wyse word die werklikheid op sy beurt vereenselwig met die waarheid en die waarheid met feite. Bybelse waarhede moet dus noodwendig die voorstelling van feitlike werklikhede wees. Dis dan wanneer daar vrae ontstaan soos onder andere oor die sondvloed en Noag se ark (Gen 6-9) en die heldedade van Simson (Rigt 1316). Probleme oor die aantal dierepare wat die ark gehuisves het en die duisend Filistyne wat Simson met 'n eselskakebeen doodgeslaan het, is bekyk vanuit 'n postmodernistiese gesigspunt en literêre invalshoek pseudoprobleme.

Die geskiedenis van Simson, opgeteken in hoofstuk 13 tot 16 van die boek Rigters, is die verhaal van 'n man wie se roeping en talente wat hy van God ontvang het, in stryd is met sy menslike aard en natuurlike drifte en gawes. ${ }^{5}$ Soos in 'n Griekse tragedie voltrek Simson se lot hom in die voortgang van onstuitbare gebeure wat mekaar met dodelike reëlmaat opvolg. God roep Simson om Israel te rig en te bevry van die juk van die Filistyne waaronder hulle reeds vir veertig jaar gebuk gegaan het. Maar Simson is aangetrokke tot die Filistyne, veral tot hulle vroue. Teen sy ouers se sin en wil in laat hy hom met 'n Filistynse vrou uit Timna in die eg verbind. Onderweg na die huweliksfees gaan soek hy na die karkas van 'n leeu wat hy, toe hy ' $n$ vorige keer op pad was na Timna, verskeur het en sien dat die bye daarin nes gemaak het. Hy haal vir hom van die heuning daaruit en gee ook daarvan aan sy ouers om te eet.

Hierdie Israelitiese Hercules is nie net reuse-sterk nie, hy is ook woorden vindingryk. Sy vonds van die heuning in die leeukarkas, is die inspirasie vir ' $n$ raaisel wat hy stel aan die dertig jongmanne wat soos die gebruik was, vir die duur van die huweliksfees aan hom gegee is as sy eskorte: "Spys het uit die eter uitgegaan en soetigheid uit die sterke" (Rigters 14:14). As hulle dit tydens die sewedaagse fees vir hom kon uitlê, sou hy vir hulle dertig stelle klere gee; anders moes dit hulle geskenk aan hom wees. Onder doodsdreigemente van haar volksgenote het sy vrou by hom geneul totdat hy haar die antwoord gegee het: "Wat is soeter as heuning, en wat is sterker as 'n leeu?" (Rigters 14:18). Voordat Simson in woede teruggekeer het na sy ouerhuis by die besef dat hy uitoorlê is, het hy dertig Filistyne in die dal van

\footnotetext{
${ }^{5}$ Ek erken hiermee graag my skatpligtigheid aan ds J Overduin (1963:128-138) vir sy weergawe van die verhaal van Simson in sy boek Profetische vergezichten. Ds Overduin het my deur sy oorvertelling met nuwe oë na Simson laat kyk deur die aksente wat hy lê. My interpretasie gaan in vele opsigte terug op sy weergawe, maar anders as hy gee ek nie aan hierdie Ou-Testamentiese verhaal 'n Christelike betekenis deur die lyn deur te trek na Hebreërs 11:32 nie.
} 
Askelon doodgeslaan en hulle uitrustings gegee aan diegene wat die raaisel opgelos het (Rigters 14:19).

Met hierdie inleidende gebeure tot sy volwassenheid is die patroon van Simson se lewe vasgelê: dit word gekenmerk deur toenadering tot en distansiëring van die Filistyne. As hy terugkeer na sy Timnitiese vrou, moet hy ontdek dat haar vader haar aan 'n metgesel van hom as eggenote gegee het. Hy neem wraak deur driehonderd jakkalse te vang en hulle sterte twee-twee aan mekaar vas te bind met 'n fakkel daartussen in, dit aan die brand te steek en die jakkalse in die ongesnyde graan van die Filistyne los te laat (Rigters 15:4, 5). Uit weerwraak verbrand die Filistyne die huise van Simson se skoonvader en sy vrou. Weereens wreek hy hom: hy slaan die Filistyne lendelam en gaan woon in 'n rotsskeur by Etam.

Dit is nie vreemd dat die Israeliete nie vertroue in hulle leier het nie. Hulle is moeg vir Simson se konflikte met die Filistyne en lewer hom aan hulle uit. Maar die Filistyne juig te gou. Simson breek die toue waarmee hy gebind was, kry 'n vars eselskakebeen en slaan duisend manne daarmee dood (Rigters 15:15). Nou loop hy oor van selfvertroue, in so 'n mate dat hy spog met sy "heldedaad" en God nie daarvoor dank nie, maar Hom verkwalik dat Hy hom laat dors ly. Op sy verwyt, laat God vir hom 'n fontein opborrel by Legi waar hy hom na die slag bevind.

Ná 'n kort tussenspel waartydens hy 'n Filistynse prostituut besoek, volg die bekende liefdesgeskiedenis van Simson en Delila wat onder andere die opera van Camille Saint-Saens "Samson et Dalila" geïnspireer het en in Afrikaans Olga Kirsch se gedig "Gaza" (Die soeklig). Veral aangrypend is die Engelse digter John Milton se weergawe van die blinde Simson se gemoedstoestand waarmee hy hom as blinde volkome kon identifiseer: "O dark, dark, dark amid the blaze of noon." Die tragiese gevoel wat hierdie hele verhaal deurdring, lê daarin dat Simson 'n vrou liefkry wat hom verraai. Dat dit hier werklik om liefde van sy kant gegaan het, hoef ons nie aan te twyfel nie (vgl Rigters 16:4). Indien sy dit enigsins beantwoord het - wat te betwyfel is het haar patriotisme die oorhand gekry oor haar liefde.

As Delila op aandrang van haar volksgenote Simson na sy krag begin vra, begin hy met haar 'n spel te speel waardeur hy sy hoogmoed en grootpraterigheid kan botvier. Op haar vrae oor hoe sy krag aan bande gelê kan word, kry ons drie van sy antwoorde waarmee hy haar mislei het, te hore: hy moes vasgebind word met sewe vars lyne (Rigters 16:7); met sewe nuwe toue (Rigters 16:11); sy moes sy haarlokke met 'n pen aan mekaar en aan 'n weefstoel vasbind (Rigters 16:13). Met die waarskuwing: "Die Filistyne is op jou, Simson!" ruk hy hom telkens los en ontsnap. 
Van ontsnapping tot ontsnapping styg die spanning en stuur Simson se lewe onkeerbaar af op sy tragiese einde. As hy tot sterwens toe sat is van Delila se geneul, vertel hy haar die waarheid. Sy maak hom op haar skoot aan die slaap en skeer sy hare af. Dié keer is hy magteloos as sy hom waarsku en hy word gevange geneem. Sy oë word uitgesteek en van nou af moet hy in die gevangenis in Gasa koring maal.

Nie net Simson nie, maar ook sy God, die God van Israel, het oënskynlik die onderspit gedelf teen die Filistyne en hulle god Dagon. Wanneer hulle 'n offerfees in die tempel van Dagon hou om hom te dank vir hulle oorwinning, laat hulle Simson haal om hulle te vermaak. Maar die bespotte blinde se hare het weer gegroei en sy krag het teruggekeer. Hy leun teen die pilare aan waarop die tempel rus en bid tot God om hom toe te laat om hom nog dié een keer op sy vyande te wreek. Met die woorde: "Laat my sterwe saam met die Filistyne!" trek hy die pilare om op hom en al die feesvierendes (Rigters 16:30). So betaal hierdie in homself verskeurde mens die hoogste prys vir sy sondes en gee hy deur sy vrywillige dood uiteindelik aan God die volle eer. (Daar is uiteraard ook ander interpretasies moontlik.) Ten slotte sterf Simson tot eer van God, maar saam met die "vyande" tot wie hy hom aangetrokke gevoel het en by wie hy kennelik tuis was. Daarin lê ' $n$ groot stuk ironie opgesluit.

Simson is van dié menslike substansie waaruit alle groot tragiese figure in die wêreldliteratuur gemaak is. Dit is ' $n$ geïnspireerde verhaal waarin die verbeelding 'n groot rol speel, daarom is vrae of dit vir een man, al is hy ook hoe sterk, moontlik is om driehonderd jakkalse te vang en hulle sterte aan mekaar te bind en of hy duisend manne met 'n eselskakebeen dood kan slaan, volkome irrelevant.

\section{BESLUIT}

Ek is nie 'n ongeskrewe vel papier nie; ek is die resultaat van alles en almal wat my as mens gevorm het. Daaronder neem die Nederduitse Gereformeerde kerk 'n prominente en die Bybel 'n onaantasbare plek in. My eie aard, my bepaalde gawes en my eiesoortige menslike ervarings speel vanselfsprekend ' $n$ rol in hoe en wat ek dink, ook oor God en Jesus en die Christelike geloof. My beeld van God vorm ek vanuit my eie ervarings en denke - waaronder al my leeservarings - maar hierdie beeldvorming geskied altyd in samespraak met tekste en daarvan is die Bybel vir my die belangrikste. Daarmee sê ek nie dat die Bybel vir my die enigste openbaring van God is nie: die natuur en die kunste is dit ook en wel in 'n hoë en besondere mate. 
Met die Bybel as die "Boek" van my geloofstradisie kom ek wel in konflik as dit hanteer word as dié waarheid, in so 'n absolute sin, dat wanneer jy jou daarop beroep die finale woord gespreek is: "Die Bybel sê so, daarom is dit so." Die interpretasie van die Bybel vanuit die belydenisskrifte vind ek net so problematies. Ek is daarvan oortuig dat die Bybel om betekenisvol te wees, weer geyk moet word as die Joodse boek wat dit in der waarheid is. Die Ou Testament is al veels te lank vervals tot 'n boek wat net betekenis het in soverre dit vooruitwys na die Nuwe Testament. Vooraanstaande Duitse en Nederlandse teoloë opponeer hierdie siening deur te praat van die "Eerste" en die "Tweede Testament". Wiersinga gaan nog verder en noem die Ou Testament die "Joodse bybel." Tereg, glo ek.

Die Bybel word weer die lewende verhaal van God wat met die mens onderweg is as die leser hom kan bevry van die Grieks-Romeinse beeldvorming van die Bybel wat reeds vir eeue aan ons opgedring word. Ek het in my godsdienstige belewenis die verhale van die Joodse bybel en die verhaal van Jesus nodig om iets van God te verstaan. Die influisteringe wat my verse inspireer en die stem van my gewete bring my in aanraking met "iets" of "iemand" buite myself. Dié aanraking, veral as impuls vir die skryf van 'n gedig, is vir my 'n religieuse ervaring.

Op grond van hierdie intense eie ervaring van die kreatiewe impuls vind ek aanklank by Friedrich Schleiermacher van wie Gerrit Manenschijn (2001:141) sê dat hy die belang van religieuse ervaring diepgaande gepeil het. Omrede van my bewussyn van die "Diesseits" en die "Jenseits" wat blyk uit my bundeltitels - dié van my debuut Digby Vergenoeg (1971) en van my jongste bundel, die agste uit my pen, Duskant die einders (2004) - het ek groot begrip vir Schleiermacher se omskrywing van die wese van die religie as die intensiewe aandag vir die raaiselagtige samehang tussen eindigheid en oneindigheid (Manenschijn 2001:129).

Maar met 'n pluraliteit van persoonlike ervarings kom ons nêrens. Ek gee Manenschijn (2001:124) volkome gelyk as hy besluit: "Waren er geen verhalen over God geweest dan was er nooit over openbaring en ervaring gesproken. We moeten terug naar de primaire vorm van gemeenschappelijke godervaring: het verhaal van God en mens. Dat verhaal wordt verteld in de taal van het geloof, en die taal maakt gebruik van metaforen en symbolen." Dit beteken: terug na die Bybel waaronder die postmodernisme die GrieksLatynse onderbou weggehaal het om aan die verhale daarin vervat die moontlikheid te laat om hulle volle betekenis te kry.

Ek het geen aanleg vir die mistiek nie; die naaste wat ek kan kom aan 'n mistieke ervaring is deur die skrywe van 'n gedig en die luister na die musiek van die groot komponiste. Dit ontbreek my daarbenewens aan die 
dissipline om my te oefen in meditasie. Terwyl die irrasionele seerseker in my lewe ' $n$ prominente rol speel, is ek as gevolg van my rasionaliteit, my estetiese vorming en poëtiese ingesteldheid nie daartoe in staat om enige aanklank by 'n charismatiese geloofsbelewenis te vind nie.

In volledige instemming met Wiersinga (2000:186) glo ek in God omdat ek in die liefde glo. Daarom kan ek ook sê dat God vir my liefde is. Die "God van die Ou Testament" is nie, soos dikwels beweer word, slegs ' $n$ "wrede God" nie. Dis immers 'n liefdevolle God wat sy Joodse profeet Jona stuur om aan die goddelose en heidense stad Ninevé sy oordeel te gaan verkondig en op hulle bekering - tot Jona se bittere verontwaardiging - afsien van sy voorneme om die stad te vernietig. In teenstelling met sy hardvogtige profeet het God deernis met die inwoners van Ninevé, veral met die kinders en diere (Jona 4:11). Dis betreurenswaardig dat in kerklike kringe nog geredekawel word of Jona in die vis se buik was of nie - asof die waarheid van die boek daarvan afhang. Fundamentaliste dring ook in hierdie geval aan op die feitlike waarheid: die verhaal móét 'n getroue weergawe van die werklikheid wees.

As ek sê dat God vir my liefde is, vermy ek bewus die formulering ' $n$ "God van liefde". Om te praat van 'n "God van liefde" is om onmiddellik die vraag op te roep wat altyd weer deur ateïste gestel word: "Hoe kan 'n God van liefde?" - met alles wat daarop volg. Dit is nog steeds die God van die belydenisskrifte aan wie hier getwyfel word en, inderdaad, waarom gryp 'n alwetende, almagtige, liefdevolle God nie in op die geskiedenis op so 'n wyse dat Hy Hom bo alle twyfel kenbaar maak nie? Hierdie vraag konfronteer my met die brandende aktuele inhoud wat dit na die Tweede Wêreldoorlog gekry het. In die lig van die insigte wat die na-oorlogse teologie my egter bygebring het, vra ek gelukkig nie meer waar God in Auschwitz was nie, maar waar die mens vir sy/haar medemens was.

God het ná Auschwitz sy morele gesag definitief verloor. Om op grond daarvan en van soortgelyke rampsalige gebeure jou toevlug te neem tot aangepaste voorstellings van God is, soos Gerrit Manenschijn (2001:100) dit stel, om van "de wal van de twijfel in de sloot van het ongeloof" te geraak. Hy wys daarop dat om te beweer dat "God bestaat en de geschiedenis leidt" (God bestaan en die geskiedenis stuur) 'n voorwetenskaplike denkwyse is en dat ons met sulke denkwyses in die sfeer van spekulasie bly. Dié wete moet ons weerhou van "ondoordachte aanpassingen" van ons Godsvoorstellings by ervarings van "gruwelijke wreedheden die die wereld teisteren en die door mensen worden begaan, niet door God" (Manenschijn 2001:100).

Die gesprek tussen die kerk en die sinagoge wat wêreldwyd gevoer word, het hier nog skaars ' $n$ rimpeling veroorsaak. In die Grieks/Latynse beeldvorming van Jesus soos weerspieël in die Ortodokse Christendom is sy 


\section{Die Bybel in die geding: Teks versus dogma}

Joodwees heeltemal weggesyfer. Die enkele progressiewe teoloë, die sogenaamde "nuwe hervormers", wat dít beklemtoon, word onmiddellik verketter. In sy bydrae tot die publikasie Die nuwe hervorming met die sprekende titel "Rabbi Jeshua van Nasaret" vat Pieter Botha die kernpunt van die debat oor Jesus se Joodwees bondig saam: "Die implikasie van die ontkenning dat Jesus ' $n$ Jood was, is immers dat hy eintlik niemand was nie" (Botha 2002:188).

Dis ondenkbaar dat Jesus as vrome Jood hom ooit aan God gelyk kon geag het. Vir bevestiging hoef 'n mens maar net sy gesprek met die Samaritaanse vrou te herlees: "God is Gees; en die wat Hom aanbid, moet in gees en waarheid aanbid" (Joh 4:24). Karen Armstrong (1996:98) sê in dié verband: "The development of Christian belief in the Incarnation was a gradual, complex process. Jesus himself certainly never claimed to be God." Dat die skrifte, waarin hy sou figureer, as deur God geïnspireer beskou sou word, sou Jesus ewe veel geskok het as dat hy tot God verhoog is of soos Botha (2002:182) dit stel: "Die idee dat toekomstige mense, wat net mense is, briewe en ander tekste beskou as deur God geïnspireer, sou waarskynlik vir hom 'n godslasterlike gedagte gewees het."

Vir my is Jesus nie 'n "kind van God" soos wat ons almal "kinders van God" is nie. Vir my is hy 'n glimp van God, maar van so 'n deurdringende helderheid dat die uitstraling daarvan mense tot in die een-en-twintigste eeu verlig. Jesus is vir my beslis geen mitologiese figuur nie, daarom is die kerkleer oor sy maagdelike geboorte - 'n produk van die Grieks-Romeinse denke oor "goddelike seuns" - vir my mitologies en verwerplik.

Ons moet Jesus bevry uit die Romeinse keiserskleed waarin die Latynse kerkvaders hom geharnas het; ons moet die Griekse toga wat ons hom omgehang het, afhaal en hom weer die kleed aantrek wat hy as vrome Jood gedra het. Ons moet sy Joodse uiterlike aan hom teruggee, want na Auschwitz durf ons nie meer aan hom die voorkoms opdring van 'n blonde Ariër met blou oë nie. Ons moet die verlore Seun laat terugkeer na die huis van sy Vader en aan die voete gaan sit van die wysheidsleraar rabbi Jeshua van Nasaret. Miskien leer ons dan langsamerhand weer iets begryp van die grootheid en onuitsêbaarheid van God.

\section{Literatuurverwysings}

Achterberg, G 1967. Verzamelde gedichten. Amsterdam: Querido.

Armstrong, K 1996. A history of God. Londen: Reed International Books.

Barnard, Willem 2004. Anno Domini: Dagboeken 1978-1992. Amsterdam: de Prom. Bauman, Z 1995. Modernity and the holocaust. New York: Cornell University Press. Botha, P J J 2002. Rabbi Jeshua van Nasaret, in Muller, P (red), Die nuwe hervorming, 177-195. Pretoria: Protea Boekhuis. 
De Boer, T 1999. De hemel weet hoe: Over spirualiteit en rationaliteit. Nijmegen:

Valkhof Pers.

Den Heyer, C J 2000. Ruim geloven. Zoetermeer: Uitgeverij Meinema.

Fromm, E 1967. The art of loving. New York: Harper \& Row.

Gardner, H 1971. Religion and literature. Londen: Faber \& Faber.

Louw, N P van Wyk. 1970. Tristia. Kaapstad: Human en Rousseau.

Manenschijn, G 2001. God is zo groot dat hij niet hoeft te bestaan. Baarn: Ten Have.

Nijhoff, M 1964. Verzamelde gedichten. Den Haag: Bert Bakker.

Opperman, D J 1984. Blom en baaierd. Kaapstad: Tafelberg.

Overduin, J 1963. Profetische vergezichten. Kampen: Kok.

Wiersinga, H 2000. Op ooghoogte: Portret van een postmodern geloof. Zoetermeer:

Uitgeverij Meinema. 